\title{
Anti-hemorrhagic effect of hydro-alcoholic extract of the leaves of Mikania glomerata in lesions induced by Bothrops jararaca venom in rats ${ }^{1}$
}

\author{
Vanessa Barreto MourãoI, Gleice Mara GiraldiI, Lia Mara Grosso Neves"I, Fernanda Oliveira de Gaspari de Gaspi ${ }^{\text {III, Rodney }}$ \\ Alexandre Ferreira Rodrigues ${ }^{\mathrm{IV}}$, Armindo Antonio Alves ${ }^{\mathrm{V}}$, Marcelo Augusto Marreto Esquisatto ${ }^{\mathrm{VI}}$, Mauricio Ventura Mazzi ${ }^{\mathrm{VII}}$, \\ Fernanda Aparecida Sampaio Mendonça ${ }^{\mathrm{VII}}$, Gláucia Maria Tech dos Santos ${ }^{\mathrm{VIII}}$ \\ IGraduate student, School of Pharmacy, Herminio Ometto University Center (UNIARARAS), Araras-SP, Brazil. Acquisition and interpretation of data, \\ technical procedures, manuscript preparation. \\ "IMaster, Assistant Professor, Herminio Ometto University Center (UNIARARAS), Araras-SP, Brazil. Acquisition of data, technical procedures, control \\ of pre and postoperative of the animals. \\ IIIPhD, Full Professor, Nucleus of Health Sciences, Herminio Ometto University Center, (UNIARARAS), Araras-SP, Brazil. Acquisition of data, \\ technical procedures. \\ ${ }^{\text {IV }} \mathrm{PhD}$, Full Professor, Phytochemistry Division, Multidisciplinary Center for Chemical, Biological and Agricultural, State University of Campinas \\ (UNICAMP), Campinas-SP, Brazil. Acquisition of data, technical procedures. \\ ${ }^{v} \mathrm{PhD}$, Full Professor, Postgraduate Program of Biomedical Sciences, Herminio Ometto University Center, (UNIARARAS), Araras-SP, Brazil. Analysis \\ and interpretation of data. \\ ${ }^{\mathrm{V}} \mathrm{PhD}$, Full Professor, Postgraduate Program of Biomedical Sciences, Herminio Ometto University Center, UNIARARAS, Araras-SP, Brazil. Analysis \\ and interpretation of data, histomorphometric examinations. \\ VIIPhD, Full Professor, Postgraduate Program of Biomedical Sciences, Herminio Ometto University Center, (UNIARARAS), Araras-SP, Brazil. \\ Conception and design of the study, interpretation of data, manuscript writing, supervised all phases of the study. \\ VIIIPhD, Full Professor, Postgraduate Program of Biomedical Sciences, Herminio Ometto University Center, (UNIARARAS), Araras-SP, Brazil. \\ Conception, design, intellectual and scientific content of the study; critical analysis; final approval.
}

\section{ABSTRACT}

PURPOSE: To investigate the effects of hydroalcoholic leaf extract of Mikania glomerata Spreng (Asteraceae) on the activity of Bothrops jararaca snake venom in Wistar rats.

METHODS: Fifty four rats Wistar were divided into six groups of nine animals in each: control treated with saline; control treated with $B$. jararaca venom; control treated with $M$. glomerata extract; $B$. jararaca venom incubated with $M$. glomerata extract at proportions of $1: 1,1: 2$, and $1: 4$.

RESULTS: Histopathological and morphometric analysis showed that intradermal administration of snake venom incubated with the hydroalcoholic extract at proportions of 1:1, 1:2 and 1:4 promoted a significant reduction in the number of inflammatory cells and a marked decrease in edema after the third hour. There was also a significant reduction in the intensity of the hemorrhagic halo in animals receiving the snake venom incubated with the extract, with the observation of a progressive and parallel inhibition with increasing proportion of $M$. glomerata.

CONCLUSION: The Mikania glomerata hydroalcoholic extract exerted effective anti-inflammatory and antihemorrhagic activity against the effects induced by Bothrops jararaca snake venom.

Key words: Snake venons. Plants, Medicinal. Mikania. Bothrops. Rats. 


\section{Introduction}

Snake venoms comprise several substances, including proteins, enzymes and peptides that can vary depending on the place, alimentation, age and gender of the animals. The Viperidae family represents an important group of snakes in public health. They are responsible for most serious ophidian accidents reported in Brazil and other occidental countries. The Bothrops genus (family Viperidae) encloses some of the most remarkable species from the medical point of view, since it contributes $73.1 \%$ of the ophidian annual accidents which occur in Brazil ${ }^{1-3}$.

Morbidity related to snake envenomation not only depends on the quantity of snake venom inoculated, but also on the chemical composition of the venom which is species specific. The venom of Bothrops jararaca primarily causes shock, tissue necrosis, intravascular coagulation, local and systemic hemorrhage, and edema ${ }^{3}$. Snake venom is a modified form of saliva that consists of a complex mixture of proteins and toxic enzymes such as phospholipases $\mathrm{A}_{2}$, myotoxins, hemorrhagic/non hemorrhagic metalloproteinases, serine proteases, neurotoxins, and cytokines, among others ${ }^{4}$. These proteins account for 90 to $95 \%$ of the dry weight of snake venoms ${ }^{5}$.

Plant extracts have been used for the treatment of snakebites because they contain a wide variety of chemical compounds with pharmacological activities that exert inhibitory activity against the toxins present in snake venom ${ }^{6-9}$. This plant has antifungal, antimicrobial, bronchodilatory, antiallergic, antihemorrhagic, and anti-inflammatory properties ${ }^{10}$. Phytochemical studies have shown that Mikania contains terpenes, essential oils ${ }^{11}$, di- and sesquiterpene lactones ${ }^{12}$, flavonoids, and stigmasterol ${ }^{13}$, alcohols, acids, esters, aldehydes, organic esters and steroids. Regarding the safety of the extracts, phytomedicines and isolated compounds, guaco species did not present significant toxic and genotoxic effects in humans ${ }^{14}$.

In a study of plants with antiophidic properties used in folk medicine, Ruppelt ${ }^{15}$ also observed anti-inflammatory activity of $M$. glomerata. The main chemical compound with medicinal activity, which has been reported to exert antiophidic activity ${ }^{16}$, is coumarin ${ }^{17,18}$. Hadjipavlou-Litina ${ }^{19}$ observed that coumarin may reduce edema and inflammation by inhibiting the synthesis of prostaglandins. Aqueous extracts prepared from several plant parts efficiently inhibit the different toxic, pharmacological, and enzymatic effects induced by the venom of Bothrops and Crotalus snakes ${ }^{14}$. Maiorano ${ }^{20}$ observed that guaco root extracts reduced the hemorrhage zone stimulated by the intradermal injection of Bothrops venom by $80 \%$ in rats suggesting that there is an interaction between the components of guaco and metalloproteases involving the catalytic sites of these enzymes or essential metal ions, thereby inhibiting their hemorrhagic activities.

Serum therapy is used as an approach to treat the local and systemic effects of snakebites. However, studies indicate that this therapy is partially effective in inhibiting the effects of the venom at the site of inoculation, which usually result in severe and irreversible injuries. Therefore, there is increasing interest in alternative coadjuvant antiophidic therapies ${ }^{21}$.

The objective of the present study was to evaluate the effects of a hydroalcoholic leaf extract of $M$. glomerata Spreng. (Asteraceae) activity on inflammatory and haemorrhagic of $B$. jararaca snake venom in Wistar rats.

\section{Methods}

The study was approved by the Ethics Committee for Animal Use of Herminio Ometto University Center - UNIARARAS (Protocol N $\mathrm{N}^{\mathrm{O}}$ 063/2010), and was conducted in accordance with international regulations on animal experimentation and biodiversity.

Fifty-four male Wistar rats (Rattus norvegicus), 120 days old and weighing on average $300 \mathrm{~g}$, were obtained from the Center of Animal Experimentation "Prof. Dr. Luiz Edmundo de Magalhães" of Hermínio Ometto University Center - UNIARARAS. The animals were maintained in individual cages at a constant temperature of 23 $\pm 2^{\circ} \mathrm{C}$ under a 12-h light/dark cycle, and received commercial chow and water ad libitum. No differences in behavior were observed between animals during the experiment.

\section{Plant material}

For the preparation of the hydroalcoholic extract, leaves of Mikania glomerata Spreng were collected in the Medicinal Plant Garden of Herminio Ometto University Center - UNIARARAS, through the "Project Health \& Harmony". The samples were identified by the botanist Gerson de Oliveira Romão of Higher School of Agriculture "Luiz de Queiróz" - ESALQ/USP, and deposited in the ESA Herbarium ( ${ }^{\circ}$ 114299).

\section{Preparation of the hydroalcoholic extract}

After collection, the M. glomerata leaves were selected, washed, dried at room temperature, and weighed. For extraction, the leaves were repeatedly macerated with $70 \%$ ethanol for 14 days. The resulting hydroalcoholic extract was evaporated at $40^{\circ} \mathrm{C}$ (Fisatom 802 Rotary Evaporator) until the complete removal of ethanol. The extract was lypophilized (VirTis ${ }^{\circledR}$ 8L Freeze Dryer) at Research Center for Chemical, Biological and Agricultural (CPQBA) - UNICAMP. 
For the inhibition studies of the hemorrhagic halo the extract was solubilized in PBS and then used the soluble fraction.

\section{Snake venom}

The Bothrops jararaca snake venom was purchased from Bioactive proteins (Serpentário Bioagents Ltda., BatataisSP, Brazil).

\section{Experimental protocol}

The M. glomerata hydroalcoholic extract (soluble fraction) was incubated with the snake venom at different proportions $(1: 1,1: 2$, and $1: 4)$ for $30 \mathrm{~min}$ at $37^{\circ} \mathrm{C}^{20}$.

The animals were divided into six groups of nine animals each. All animals were anesthetized intraperitoneally with Xylazine hydrochloride $(20 \mathrm{mg} / \mathrm{kg}$ ) and Ketamine hydrochloride $(50 \mathrm{mg}$ / $\mathrm{kg}$ ) and a trichotomy was performed in the dorsal region. After $48 \mathrm{~h}$, the animals were submitted to the following procedures after anesthesia: group G1, intradermal administration of $100 \mu \mathrm{L}$ saline; group G2, intradermal administration of $100 \mu \mathrm{L}$ B. jararaca venom at a concentration of $3.2 \mu \mathrm{g} / \mu \mathrm{L}$; group $\mathrm{G} 3$, intradermal administration of $100 \mu \mathrm{L}$ M. glomerata hydroalcoholic extract at a concentration of $15 \mu \mathrm{g} / \mu \mathrm{L}$; group $\mathrm{G} 4$, intradermal administration of $100 \mu \mathrm{L}$ B. jararaca venom $+M$. glomerata hydroalcoholic extract at a concentration of $3.2 \mu \mathrm{g} / \mu \mathrm{L}(1: 1)$; group G5, intradermal administration of $100 \mu \mathrm{L}$ B. jararaca venom $+M$. glomerata hydroalcoholic extract at a concentration of $6.4 \mu \mathrm{g} / \mu \mathrm{L}(1: 2)$; group G6, intradermal administration of $100 \mu \mathrm{L} B$. jararaca venom $+M$. glomerata hydroalcoholic extract at a concentration of $12.8 \mu \mathrm{g} / \mu \mathrm{L}(1: 4)$. The volume inoculated in each group was always the same: $100 \mu \mathrm{L}$.

One, two and three hours after intradermal administration of the venom and extract, three animals from each group were euthanized with an overdose of the anesthetic and the wound areas were collected from the different groups for photodocumentation. For this purpose, the animals were anesthetized as described above. Next, the skin was removed, photographed, and prepared for histopathological analysis. The macroscopic images were used to measure the size of the hemorrhagic halo with a pachymeter. The data were analyzed using the Posturograma 3.0 software (Fisiometer) and were compared by ANOVA $(\mathrm{p}<0.001)$ using the Origin 6.0 program. The results are reported as the mean and standard deviation of each group.

\section{Histopathological analysis}

The wound area was removed and fixed in $10 \%$ formalin in Millonig buffer, $\mathrm{pH} 7.4$, for $24 \mathrm{~h}$ at room temperature. Next, the specimens were washed in the same buffer and processed for embedding in Paraplast ${ }^{\mathrm{TM}}$ (Merck). Longitudinal sections $(5 \mu \mathrm{m})$ were stained with hematoxylin-eosin for routine histology and by the Dominici method for the quantification of inflammatory cells. The specimens were examined and photographed with a Leica DM 2000 photomicroscope. The following histopathological parameters were evaluated: acute inflammatory reaction in the dermis, edema, eosinophilic collagen fibers (denaturation and disarrangement), subcutaneous muscle necrosis, and number of inflammatory cells.

The morphological results are reported as the mean and standard deviation of each group and were compared by ANOVA and the Tukey's post-hoc test $(\mathrm{p}<0.05)$.

\section{Determination of minimum hemorrhagic dose}

The hemorrhagic activity of the venom was quantified according to the method of Ownby ${ }^{22}$, with some modifications. The animals were trichotomized in the dorsal region and anesthetized with Xylazine hydrochloride (20mg/ $\mathrm{kg}$ ) and Ketamine hydrochloride $(50 \mathrm{mg} / \mathrm{kg})$. Next, different concentrations of crude $B$. jararaca venom $(5,10,20,40,80$, 160,320 , and $640 \mu \mathrm{g}$ ) were injected intradermally. The animals were euthanized with an overdose of the anesthetic and after 1,2 and $3 \mathrm{~h}$ and their skin was removed and photographed for analysis of the formation of a hemorrhagic halo using the Posturograma program. The measurements were done in triplicate and the minimum hemorrhagic dose was defined as the minimum concentration of snake venom necessary to produce a hemorrhagic halo measuring $\mathrm{cm}$ in diameter.

The minimum hemorrhagic dose determined in the present study was $160 \mu \mathrm{g}$. However, a dose of $320 \mu \mathrm{g}$ was established for the inhibition assays to account for the dilution of the snake venom by the plant extract.

\section{Results}

Figure 1 shows the results of analysis of the histopathological effects of $B$. jararaca snake venom combined with the $M$. glomerata hydroalcoholic extract. Tissue samples of group G1 presented some inflammatory foci, mild edema, and areas of muscle necrosis at all time points studied. In addition, structural alterations in collagen fibers were observed after the third hour, which were due to the presence of eosinophilia seen during this period. 
$1 \mathrm{~h}$
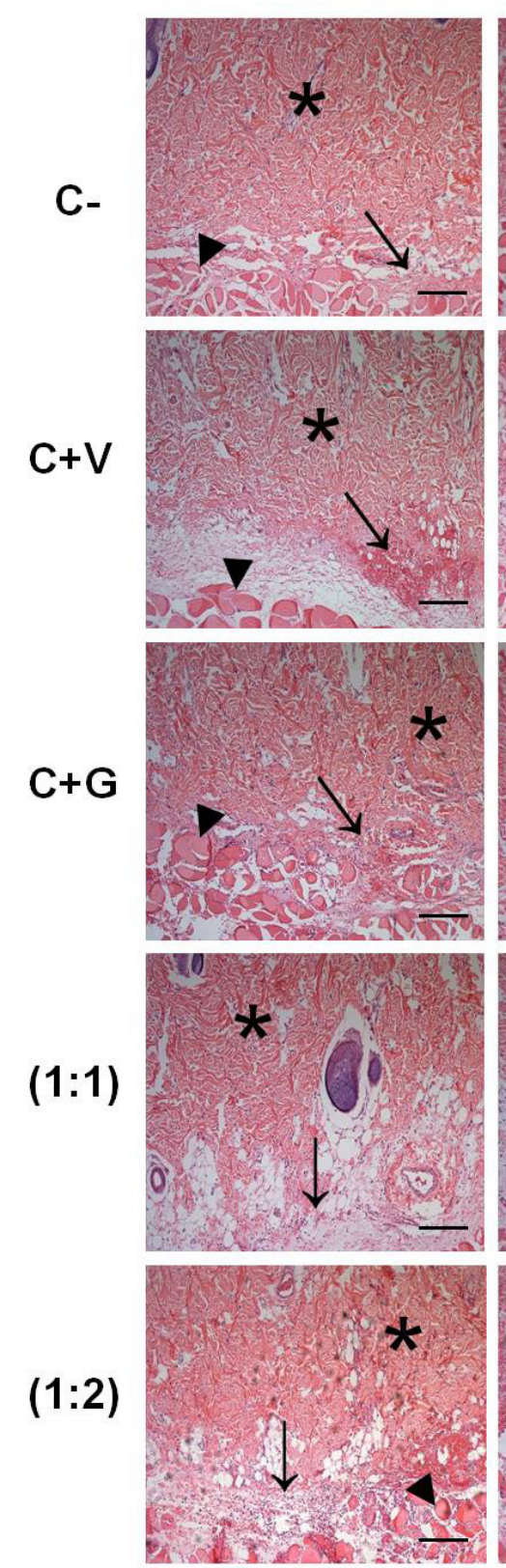

$(1: 4)$

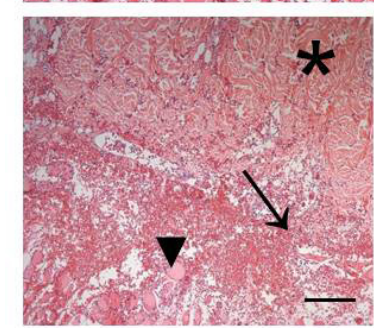

$2 \mathrm{~h}$
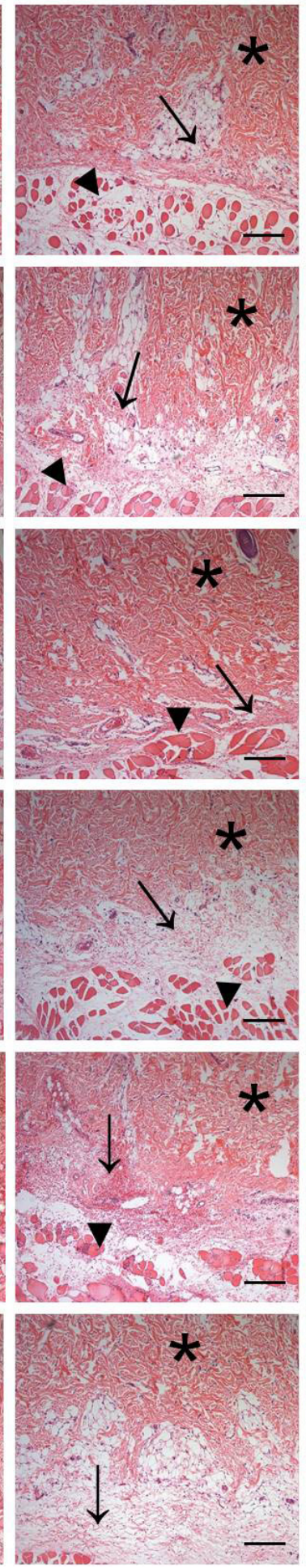

$3 \mathrm{~h}$
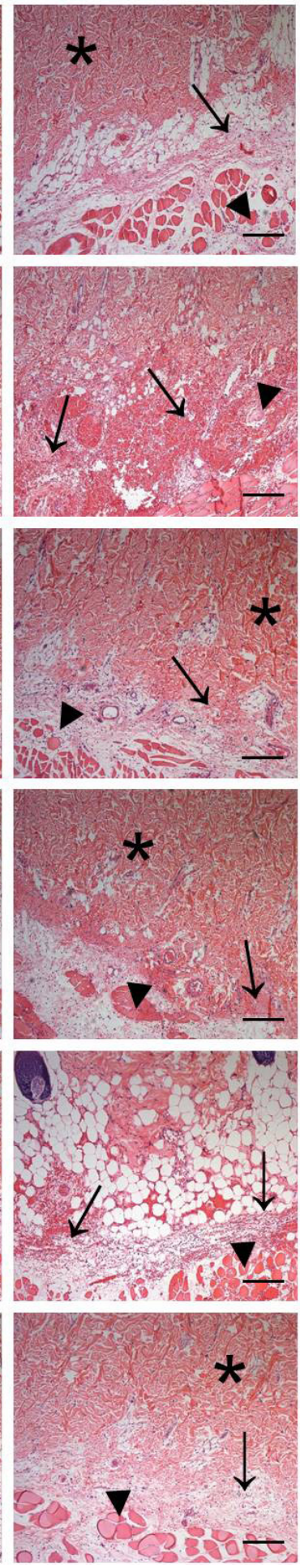

FIGURE 1 - Cross-sections obtained from the site of intradermal injury induced by Bothrops jararaca snake venom incubated with hydroalcoholic extract of Mikania glomerata Spreng. G1: intradermal administration of $100 \mu \mathrm{L}$ saline; G2: intradermal administration of $100 \mu \mathrm{L}$ B. jararaca venom at a concentration of $3.2 \mu \mathrm{g} / \mu \mathrm{L}$; G3: intradermal administration of $100 \mu \mathrm{L}$ M. glomerata hydroalcoholic extract at a concentration of $15 \mu \mathrm{g} / \mu \mathrm{L}$; G4: intradermal administration of $100 \mu \mathrm{L} B$. jararaca venom + M. glomerata hydroalcoholic extract at a concentration of 3.2 $\mu \mathrm{g} / \mu \mathrm{L}(1: 1)$; G5: intradermal administration of $100 \mu \mathrm{L}$ B. jararaca venom $+M$. glomerata hydroalcoholic extract at a concentration of $6.4 \mu \mathrm{g} / \mu \mathrm{L}(1: 2)$; G6: intradermal administration of $100 \mu \mathrm{L} \mathrm{B}$. jararaca venom + M. glomerata hydroalcoholic extract at a concentration of $12.8 \mu \mathrm{g} / \mu \mathrm{L}(1: 4)$. Tissue samples were collected 1,2 and $3 \mathrm{~h}$ after administration. The sections were stained with hematoxylin-eosin and examined under a bright-field microscope. $\left(^{*}\right)$ Collagen fibers of the deep dermis; $(\rightarrow)$ areas of inflammatory infiltration and hemorrhage; $(\rightarrow)$ areas of tissue necrosis. Bar $=100 \mu \mathrm{m}$. 
The dermis of group G2 animals was characterized by the presence of significant inflammatory foci seen as early as in the first hour, which increased over time. Interstitial edema was observed at all time points studied. Alterations of collagen fibers were seen as early as in the first hour and intense eosinophilia was observed in deeper layers of the dermis. Extensive areas of deep muscle necrosis were noted at all time points and the number of hemorrhagic foci increased over time.

The findings of group G3 were similar to those seen in group G1. However, a greater inflammatory response was observed at all time points, but important hemorrhagic foci were absent.

In group $\mathrm{G} 4$, interstitial edema was seen as early as in the first hour and was accompanied by hemorrhagic foci that became more intense after the third hour of observation. Deep muscle necrosis was observed throughout the study period, but was more evident in the third hour. The intensity of eosinophilic collagen fibers in the dermis was similar to that seen in group $\mathrm{G} 2$, especially in the third hour of observation.

The results obtained for groups G5 and G6 were similar. In these groups, the deep muscle necrosis and eosinophilic collagen fibers in the dermis were less intense than those observed in group G4. Tissue edema appeared more intense in these groups and the inflammatory infiltrate was more diffuse. In addition, hemorrhagic foci were more frequently found in the interstitium, but were less intense than those seen in group G2.

The largest number of inflammatory cells was observed in group G2, whereas the smallest number was seen in group G1 when compared to the other groups (Figure 2). No significant difference in the number of inflammatory cells was observed between groups G1, G3, G4, G5 and G6 in the first hour, but these numbers were significantly lower than those seen in group G2. In the third hour, the number of inflammatory cells in groups G4, G5 and G6 was significantly higher when compared to groups G1 and G3 but lower when compared to group G2. The results obtained for groups G4, G5 and G6 were similar (Figure 2).

A significant reduction in the intensity of hemorrhagic activity was observed at the various time points in the groups receiving an intradermal injection of $B$. jararaca venom incubated at different proportions with the $M$. glomerata hydroalcoholic extract when compared to group G2 (Figure $3)$. This reduction was most marked at the proportion of 1:4. These results indicate a progressive and parallel inhibition with increasing proportion of M. glomerata.

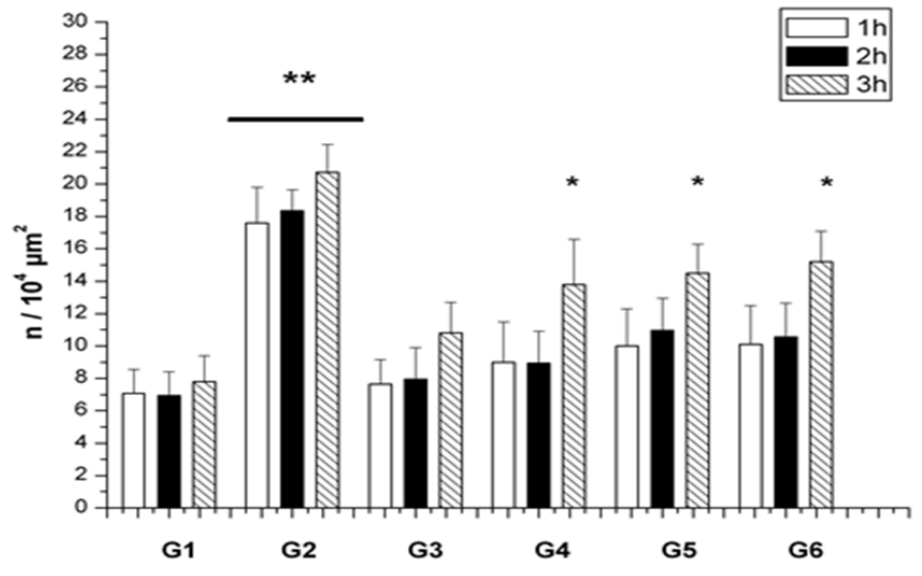

FIGURE 2 - Total number of inflammatory cells $\left(\mathrm{n} / 10^{4} \mu \mathrm{m}^{2}\right)$ at the site of intradermal injection of Bothrops jararaca snake venom incubated with hydroalcoholic extract of Mikania glomerata Spreng. G1: intradermal administration of $100 \mu \mathrm{L}$ saline; G2: intradermal administration of $100 \mu \mathrm{L} B$. jararaca venom at a concentration of $3.2 \mu \mathrm{g} / \mu \mathrm{L} ; \mathbf{G 3}$ : intradermal administration of $100 \mu \mathrm{L} M$. glomerata hydroalcoholic extract at a concentration of $15 \mu \mathrm{g} / \mu \mathrm{L}$; G4: intradermal administration of $100 \mu \mathrm{L} \mathrm{B}$. jararaca venom + M. glomerata hydroalcoholic extract at a concentration of $3.2 \mu \mathrm{g} / \mu \mathrm{L}$ (1:1); G5: intradermal administration of $100 \mu \mathrm{L}$ B. jararaca venom + M. glomerata hydroalcoholic extract at a concentration of $6.4 \mu \mathrm{g} / \mu \mathrm{L}$ (1:2); G6: intradermal administration of $100 \mu \mathrm{L} \mathrm{B}$. jararaca venom + M. glomerata hydroalcoholic extract at a concentration of $12.8 \mu \mathrm{g} / \mu \mathrm{L}(1: 4)$. Tissue samples were collected 1,2 and $3 \mathrm{~h}$ after administration. Results are reported as the mean and standard deviation of each group and were compared by ANOVA and the Tukey's post-hoc test $(p<0.05) . *$ and $* *$ indicate significant differences between time points.

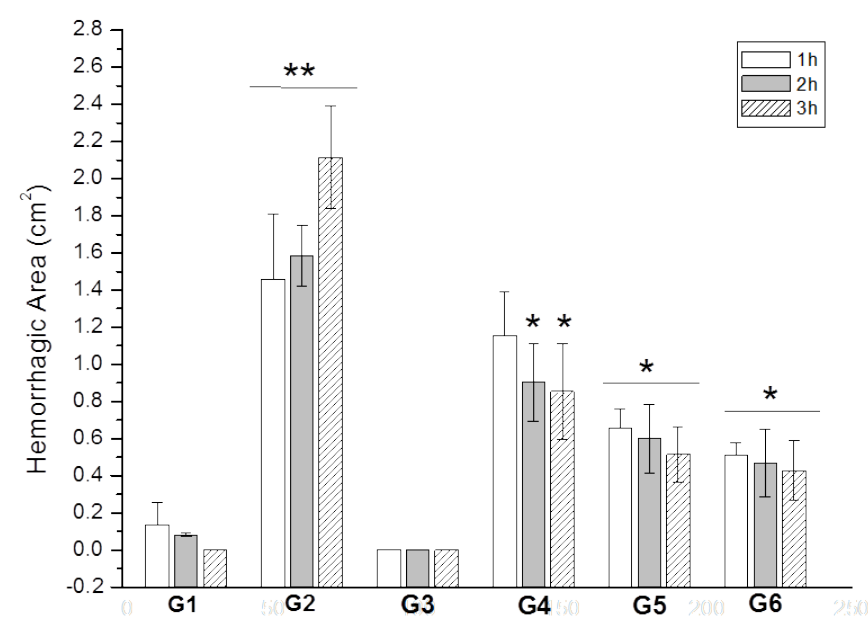

FIGURE 3 - Inhibition of hemorrhagic activity of Bothrops jararaca snake venom by the hydroalcoholic extract of Mikania glomerata Spreng. G1: intradermal administration of $100 \mu \mathrm{L}$ saline; G2: intradermal administration of $100 \mu \mathrm{L} \mathrm{B}$. jararaca venom at a concentration of $3.2 \mu \mathrm{g} / \mu \mathrm{L}$; G3: intradermal administration of $100 \mu \mathrm{L}$ M. glomerata hydroalcoholic extract at a concentration of $15 \mu \mathrm{g} / \mu \mathrm{L} ; \mathbf{G} 4$ : intradermal administration of $100 \mu \mathrm{L} B$. jararaca venom $+M$. glomerata hydroalcoholic extract at a concentration of $3.2 \mu \mathrm{g} / \mu \mathrm{L}(1: 1)$; G5: intradermal administration of $100 \mu \mathrm{L}$ B. jararaca venom $+M$. glomerata hydroalcoholic extract at a concentration of $6.4 \mu \mathrm{g} /$ $\mu \mathrm{L}$ (1:2); G6: intradermal administration of $100 \mu \mathrm{L}$ B. jararaca venom + M. glomerata hydroalcoholic extract at a concentration of $12.8 \mu \mathrm{g} / \mu \mathrm{L}(1: 4)$. The assays were performed 1,2 and $3 \mathrm{~h}$ after administration. The results are expressed as the size of the hemorrhagic area $\left(\right.$ in $\left.\mathrm{cm}^{2}\right)$ and are reported as the mean \pm standard deviation $(\mathrm{n}=3)$. * and $* *$ indicate significant differences between time points. 


\section{Discussion}

Plants with antiophidic properties have been studied by different investigators, who observed their inhibitory effects in animals inoculated with venom of snakes of the genus Bothrops B $^{20,23}$

The presence of some inflammatory foci, mild edema, and areas of muscle necrosis observed in the group $\mathrm{G} 1$ is related to early stages of healing. The initial inflammatory response involves the recruitment of cells that fight potential bacterial contamination of the wound and activate cytokine secretion to activate dermal and epidermal processes ${ }^{24}$. However, if inflammation increases beyond a certain level, it will lead to healing impairment, destruction of the early migratory effect and an arrest of the healing progression ${ }^{25}$.

The intradermal administration of $B$. jararaca snake venom incubated with $M$. glomerata hydroalcoholic extract promoted a significant reduction in the number of inflammatory cells and a marked decrease of edema in the third hour in groups G4, G5, and G6. Bothrops snake venoms are rich in phospholipases $A_{2}$, which exert a variety of toxic effects such as myonecrosis, hemorrhage, cardiotoxicity, edema, and hydrolysis of membrane phospholipids and the consequent release of plateletactivating factor ${ }^{26}$. Experimental studies have shown that the local inflammatory response induced by Bothrops snake venoms is characterized by the exudation of plasma proteins. This fact is attributed to the presence of various toxins in the venom, including metalloproteinases, serine proteases, and phospholipases $\mathrm{A}_{2}^{20,27}$. Furthermore, edema induced by $B$. asper and B. jararaca has been shown to increase the levels of prostaglandin E2 ${ }^{28}$. The present results seem to confirm these observations, i.e., the inflammatory activity of $B$. jararaca venom was probably triggered by these toxins and the significant anti-inflammatory effects observed in the third hour after intradermal administration of the venom incubated with M. glomerata hydroalcoholic extract were due to the inhibition of these inflammation-inducing toxins. Several studies have demonstrated the antiophidic effect of $M$. glomerata, which inhibits the activity of phospholipase $\mathrm{A}_{2}$ in viperid snake venoms. The inhibition of this enzyme can probably be attributed to the action of coumarin ${ }^{20,27,29}$. $\mathrm{Ma}^{30}$ studying five types of coumarins isolated from Angelica gigas and suggest that these compounds hold great promise for use as potential anti-inflammatory agents. Coumarins have a variety of bioactivities including anticoagulant, antimicrobial, vasodilatador, anti-inflammatory ${ }^{31}$.

In the present study, administration of the venom incubated with $M$. glomerata promoted significant inhibitory effects, especially at the proportion of $1: 4$, i.e., the results showed a progressive inhibition of the hemorrhagic halo in parallel to the increase in the proportion of $M$. glomerata. In addition, the most significant results were observed in the third hour after intradermal administration of the venom incubated with the extract.

Local and systemic hemorrhage is an evident sign of envenomation by snakes of the family Viperidae and the hemorrhagic activity of Bothrops venom is attributed to metalloproteinases, the major component of venom. The hemostatic mechanisms of various toxins have been characterized, including those of metalloproteinases which are directly or indirectly involved in the hemorrhagic activity of snake venoms ${ }^{32}$. The local hemorrhage observed in Bothrops envenomation is the result of extensive damage to tissues and vessel walls caused by metalloproteinases, which degrade type IV collagen, leading to capillary collapse $\mathrm{e}^{33}$.

Several studies have reported the inhibition of the hemorrhagic effects of snake venoms by plant extracts ${ }^{34}$. In the study of Maiorano ${ }^{20}$ the hemorrhagic activity of the venom of various Bothrops species was significantly inhibited by $M$. glomerata extract in mice. The authors concluded that the extract could be used as an alternative treatment to serotherapy. In the present study, comparison of the size of the hemorrhagic halo induced by the intradermal administration of $B$. jararaca snake venom incubated with $M$. glomerata extract showed the antihemorrhagic activity of the extract. This finding suggests that the soluble fraction of M. glomerata extract blocks metalloproteinases and consequently inhibits the hemorrhage triggered by these enzymes suggesting that the compounds presents in the soluble fraction, associated at conditions of pre-incubation used in experimental procedures favored the inhibition of hemorrhage.

Further studies investigating in detail the isolated chemical components of $M$. glomerata with a potential local neutralizing effect on $B$. jararaca venom are needed to better understand the mechanisms of action involved in the antihemorrhagic activity of this plant.

\section{Conclusion}

$B$. jararaca snake venom incubated with $M$. glomerata extract showed the antihemorrhagic activity of the extract.

\section{References}

1. Albuquerque HN, Costa TBG, Cavalcanti MLF. Estudo dos acidentes ofídicos provocados por serpentes do gênero Bothrops notificados no Estado da Paraíba. Rev Bio Ciênc Terra. 2004;5:1-7.

2. Domingos TFS, Moura LA, Carvalho C, Campos VR, Jordão AK, Cunha AC, Ferreira VF, de Souza MCBV, Sanchez EF, Fuly AL. Antivenom effects of 1,2,3-triazoles against Bothrops jararaca and 
Lachesis muta snakes. Biomed Res Int. 2013;2013:294289. Epub 2013 Apr 22.

3. Sgrignolli LR, Mendes GEF, Carlos CP, Burdmann EA. Acute kidney injury caused by Bothrops snake venom. Nephron Clin Pract. 2011;119:131-7.

4. Bjarnason JB, Fox JW. Hemorrhagic metalloproteinases from snake venoms. Pharmacol Ther. 1994;62:325-72.

5. Markland FS. Snake venoms and the hemostatic system. Toxicon. 1998;36:1749-800.

6. Soares AM, Januário AH, Lourenço MV, Pereira MAS, Pereira OS. Neutralizing effects of snake venoms exhibited by Brazilian plants. Drugs Future. 2004;29:1105-17.

7. da Silva JO, Coppede JS, Fernandes VC, Sant'Ana CD, Ticli FK, Mazzi MV, Giglio JR, Pereira PS, Soares AM, Sampaio SV. Antihemorrhagic, antinucleolytic and other antiophidian properties of the aqueous extract from Pentaclethra macroloba. J Ethnopharmacol. 2005;100:145-52.

8. Oliveira CZ, Maiorano VA, Marcussi S, Sant'Ana CD, Januário AH, Lourenço MV, Sampaio SV, França SC, Pereira PS, Soares AM. Anticoagulant and antifibrinogenolytic properties of the aqueous extract from Bauhinia forficata against snake venoms. J Ethnopharmacol. 2005;98:213-6.

9. Santhosh MS, Hemshekhar M, Sunitha K., Thushara RM, Jnaneshwari S, Kemparaju K, Girish KS. Snake venom induced local toxicities: plant secondary metabolites as an auxiliary therapy. Min Rev Med Chem. 2013;13:106-23.

10. Holetz FB, Pessini GL, Sanches NR, Cortez DAG, Nakamura $\mathrm{CV}$, Filho BPD. Screening of some plants used in the Brazilian Folk-Medicine for the treatment of infectious diseases. Mem Inst Oswaldo Cruz. 2002;97:1027-31.

11. Ohkoshi E, Kamo S, Makino M. Fujimoto Y. ent-Kaurenoic acids from Mikania hirsutissima (Compositae). Phytochemistry. 2004;65:885-90.

12. Rüngeler P, Brecht V, Tamayo-Castillo G, Merfort I. Germacranolides from Mikania glomerata. Fitoterapia. 2001;56:475-89.

13. Aguinaldo AM, Padolina WG, Abe FYT. Flavonoids from Mikania cordata. Biochem System Ecol. 2003;31:665-8.

14. Gasparetto JC, Campos FR, Budel JM, Pontarolo R. Mikania glomerata e M. laevigata: Estudos agronômicos, genéticos, morfoanatômicos, químicos, farmacológicos, toxicológicos e uso nos programas de fitoterapia do Brasil - Uma revisão. Rev Bras Farmacogn. 2010;20:627-40.

15. Ruppelt BM, Pereira EF, Gonçalves LC, Pereira NA. Pharmacological screening of plants recommended by folk medicine as anti-snake venom. I. Analgesic and anti-inflammatory activities. Mem Inst Oswaldo Cruz. 1991;86:203-5.

16. Pereira NA, Pereira BMR, Nascimento MC, Parente JP, Mors WB. Pharmacological screening of plants recommended by folk medicine as anti-snake venom. IV. Proction against jararaca venom by isolated constituints. Planta Med. 1994;60:99-100.

17. Bertolucci SK, Pereira ABP, Ribeiro JEA, Oliveira JÁ, Braga A, Castro F. Development and validation of an RP-HPLC method for quantification of cinnamic acid derivatives and kaurane-type diterpenes in Mikania laevigata and Mikania glomerata. Planta Med. 2009;75:280-5.

18. Medeiros J, Kanis LA. Evaluation of PEG effects on the extracts obtaining from Passiflora edulis Sims, Passifloraceae, and Mikania glomerata Spreng., Asteraceae. Rev Bras Farmacogn. 2010;20:796-802.
19. Hadjipavlou-Litina D, Kontogiorgis C, Pontiki E, Dakanali M, Akoumianaki A, Katerinopoulos HE. Anti-inflammatory and antioxidant activity of coumarins designed as potential fluorescent zinc sensors. J Enzyme Inhib Med Chem. 2007;22:287-92.

20. Maiorano VA, Marcussi S, Daher MAF, Oliveira CZ, Couto LB, Gomes OA, França SC, Soares, Pereira PS. Antiophidian properties of the aqueous extract of Mikania glomerata. J Ethnopharmacol. 2005; 102:364-70.

21. Tene V, Malagón O, Finzi PV, Vidari G, Armijos C, Zaragoza T. $\mathrm{Na}$ ethnobotanical survey of medicinal plants used in Loja and Zamora-Chinchipe, Ecuador. J Ethnopharmacol. 2007;111:63-81.

22. Ownby CL, Colberg TR, Odell GV. A new method for quantitating hemorrhage induced by rattlesnake venoms: ability of polyvalent antivenom to neutralize hemorrhagic activity. Toxicon. 1984;22:227-33.

23. Vilar JC, Carvalho CM, Furtado MFD. Effects of the aqueous extracts of plants of the genera Apodanthera (Ucurbitaceae) and Jatropha (Euphorbiaceae) on the lethality of the venom of Bothrops jararaca (Serpentes, Viperidae). Bio Gera Exper. 2007:7:32-9.

24. Jones SG, Edwards R, Thomas DW. Inflammation and wound healing: the role of bacteria in the immuno-regulation of wound healing. Int J Low Extrem Wounds. 2004;3:201-8.

25. Diegelmann RF, Evans MC. Wound healing: an overview of acute, fibrotic and delayed healing. Front Biosci. 2004;9:283-9.

26. de Paula RC, Castro HC, Rodrigues CR, Melo PA, Fuly AL. Structural and pharmacological features of phospholipases $\mathrm{A}_{2}$ from snake venoms. Protein Pep Lett. 2009;16:899-907.

27. Floriano RS, Nogueira RMB, Sakate M, Laposy CB, Motta YP, Sangiorgio F, David HC, Nabas JM. Effect of Mikania glomerata (Asteraceae) leaf extract combined with anti-venom serum on experimental Crotalus durissus (Squamata: Viperidae) envenomation in rats. Rev Biol Trop. 2009;57:929-37.

28. Olivo RA, Teixeira CFP, Wallace JL, Gutiérrez JM, Zamuner SR. Role of cyclooxygenases in oedema-forming activity of bothropic venoms. Toxicon. 2007;49:670-7.

29. Collaço RCO, Rocha Jr DS, Silva MG, Cogo JC, OshimaFranco Y, Randazzo-Moura, P. Propriedade antiofídica do extrato metanólico de Mikania laevigata sobre as ações biológicas induzidas pelo veneno de Philodryas olfersii na junção neuromuscular. REU. 2010;36:105-13.

30. Ma CJ, Kim SH, Lee KY, Oh T, Kim SY, Sung SH, Kim YC. ESP102, a combined extract of Angelica gigas, Saururus chinensis and Schizandra chinensis, protects against glutamate-induced toxicity in primary cultures of rat cortical cells. Phytother Res. 2009;23:1587-91.

31. Garcia-Argaez AN, Apan TOR, Delgado HP, Velazquez G, Martinez-Vazquez M. Anti-inflammatory activity of coumarins from Decatropis bicolor on TPA ear mice model. Planta Med. 2000;66:279-81.

32. Kamiguti AS, Hay CRM, Theakston RDG, Zuel M. Insights into mechanism of hemorrhage caused by snake venom metalloproteinases. Toxicon. 1996;34:627-42.

33. Gutiérrez JM, Rucavado A. Snake venom metalloproteinases: their role in thepathogenesis of local tissue damage. Biochimie. 2000;82:841-50.

34. Januário AH, Santos, SL, Marcussi, S, Mazzi MV, Pietro RC, Sato DN, Ellena J, Sampaio SV, França SC, Soares AM. Neo-clerodane diterpenoid, a new metalloprotease snake venom inhibitor from Baccharis trimera (Asteraceae): anti-proteolytic and antihemorrhagic properties. Chem Biol Interact. 2004;150:243-51. 


\section{Acknowledgements}

To Herminio Ometto Foundation and Institutional Program for Scientific Initiation Scholarships/National Council for Scientific and Technological Development (PIBIC/CNPq).

\section{Correspondence:}

Gláucia Maria Tech dos Santos.

Centro Universitário Hermínio Ometto-UNIARARAS

Avenida Doutor Maximiliano Baruto, 500

13607-339 Araras - SP Brasil

Tel.: (55 19) 35431474 - ramal 245

glauciasantos@uniararas.br

Received: Sept 23, 2013

Review: Nov 22, 2013

Accepted: Dec 20, 2013

Conflict of interest: none

Financial source: PIBIC/CNPq (108113/2010-8)

${ }^{1}$ Research performed at Center for Animal Experimentation "Prof. Dr. Luiz Edmundo de Magalhaes", Laboratory for Research 1, Postgraduate Program in Biomedical Sciences, Herminio Ometto University Center, Araras University (UNIARARAS), Araras-SP and Research Center for Chemical, Biological and Agricultural (CPQBA), Campinas University (UNICAMP), Brazil. 